\title{
Children of Immigrants in Schools in New York and Amsterdam: The Factors Shaping Attainment
}

\author{
by Maurice Crul \& Jennifer Holdaway - 2009
}

Background/Context: This article considers the ways in which school systems in New York City and Amsterdam have shaped the educational trajectories of two groups of relatively disadvantaged immigrant youth: the children of Dominican immigrants in New York and the children of Moroccan immigrants in Amsterdam. It describes the salient features of the two educational systems and the ways in which they structure opportunity for children of immigrants. In terms of public policy, the United States and the Netherlands have taken quite different approaches toward the integration of immigrant students: The Netherlands actively seeks to integrate students and provides additional funds and special programs, whereas the United States has taken a more laissez-faire approach.

Purpose/Objective/Research Question/Focus of Study: The article analyses available data on young second-generation Moroccan and Dominican youth and their school careers in two cities: New York and Amsterdam. It aims to look at the influence of institutional arrangements and the way that the educational system facilitates or hampers the educational integration of two highly disadvantaged groups.

Research Design: The article is based on available data on the Moroccan population in Amsterdam and the Dominican population in New York. This includes primarily the Dutch SPVA surveys and other local Amsterdam studies, and the Immigrant Second-Generation in Metropolitan New York (ISGMNY) study.

Conclusions/Recommendations: Both Moroccans in Amsterdam and Dominicans in New York show relatively low levels of educational attainment. Drawing on data from a number of studies of Moroccans in Amsterdam and on the ISGMNY study, the article shows that although differently structured, neither school system does an adequate job of serving disadvantaged immigrant students. It is interesting, however, that opportunities and impediments for the two groups are shaped differently and appear at different times in the school career. Successful practices in both countries show how extra investment of resources can increase equality of opportunity.

The performance of education systems can be evaluated on many levels, but one of the most important is their effectiveness in serving disadvantaged students, a population that, in both Europe and North America, increasingly includes the children of immigrants. This article considers the ways in which school systems in New York City and Amsterdam have shaped the educational trajectories of two groups of relatively disadvantaged immigrant youth - the children of Dominican immigrants in New York and the children of Moroccan immigrants in Amsterdam, Netherlands.

In terms of public policy, the United States and the Netherlands have taken quite different approaches toward the integration of immigrant students. Whereas the Netherlands actively seeks to integrate students and to provide additional funds and special programs, the United States has taken a more 
laissez-faire approach. In New York City, immigrant students do not receive additional funds on the basis of their ethnic background, although they may be eligible for special programs if they are from poor families.

One might therefore expect children of immigrants in Amsterdam to be faring significantly better than those in New York in terms of their educational attainment. In fact, both Moroccans in Amsterdam and Dominicans in New York show relatively low levels of educational attainment, significant unemployment, and other difficulties. As this article shows, other factors are also important in shaping educational trajectories of children of immigrants, including the ways in which school choice is structured and linked to residential segregation, the ways in which students are tracked onto college or vocational paths, and the articulation between schools and the labor market. In this article, we examine how these factors combine to generate outcomes that are somewhat similar in the two cities despite differences in approach to integration at the level of national policy.

\section{DOMINICANS IN NEW YORK AND MOROCCANS IN AMSTERDAM}

We have chosen to compare the experiences of second-generation Moroccans and Dominicans because, although they differ in some important ways - most notably religion - there are some strong similarities in their social situations. Both are the children of poor labor migrants with low levels of education who arrived in the host country at a time when manufacturing employment was on the decline. Both groups are also are racially stigmatized and stereotyped. In seeking to assess the effectiveness of different education systems in serving the most disadvantaged students, an examination of their experiences should prove useful. In addition to reviewing our current knowledge, we seek to identify a series of questions for further research to be conducted in the two cities.

Dominicans are the single largest national origin group of immigrants in New York City, reflecting the long history of U.S. intervention in the Dominican Republic and the political and economic ties between the two nations. Until the 1960s, Dominican migration to the United States was minimal because exit was strictly controlled by the Trujillo regime; the 1960 census counted only 9.223 Dominicans. The overthrow of the Trujillo in 1961 led to a sudden outflow, first of his supporters, and later, following an American-assisted coup against the left-wing government that replaced him, of labor activists and dissident students (Grasmuck \& Pessar, 1991; Pessar, 1995).

Economic problems soon led to a much broader wave of migration that swamped this original group. Foreign debt, rising oil prices, and limited employment opportunities for growing numbers of college-educated Dominicans led to high rates of emigration. Although the first to leave were mostly middle-class, relatively educated people from Santiago and other urban areas, they were later joined by rural migrants (including both wealthy landowners and poor agricultural laborers) and by working-class relatives of the original migrants. Although the majority of Dominicans entered the United States legally, a significant but unknown number entered on tourist visas that they subsequently overstayed, or came through the U.S.-Mexico border without valid papers. The Dominican population in New York grew rapidly, exceeding 200,000 by 1990. The 2000 census counted 407,473 people of Dominican ancestry in New York, or about 5\% of a population of just over 8 million. But researchers' estimates put the number at least $50 \%$ higher, at close to 600,000 (Logan, 2001).

Early arrivals from the Dominican Republic settled mostly in Manhattan's Lower East Side, but over the course of the 1960s, many moved to the outer boroughs, to neighborhoods like Bushwick in Willamsburg, Brooklyn, Corona in Queens, or, mostly, to Washington Heights on the northern tip of Manhattan. Washington Heights is now a lively ethnic community where, Luis Guarnizo estimated in 1992, there were at least 1,500-2,000 Dominican-owned enterprises, including travel agencies, bodegas, and gypsy cab operators (Guarnizo, 1994).

The first Moroccan labor migrants came to the Netherlands in the beginning of the 1960s on their 
own initiative. Many of them had worked briefly in Belgium or Germany before trying their luck farther north. The continuing demand for low-skilled workers in the Dutch textile and metal industries triggered a process of chain migration by relatives and friends from their home countries. In 1964, the Netherlands signed official agreements on labor migration with Morocco. Dutch industry needed low-skilled labor, and the majority of these first-generation Moroccan "guest workers" were recruited from the lowest socioeconomic strata in their home country. The labor migration recruitment was aimed only at men. Women came much later when they joined their spouses. The peak of labor migration occurred between 1970 and 1974, when official migration was halted (Crul \& Doomernik 2003).

Amsterdam-West is the "capital" of the Dutch Moroccans in the Netherlands. In 2004, about $8 \%$ of the Amsterdam population was of Moroccan descent (Crok, Slot, Fedorova, Janssen, \& ten Broeke, 2004), making it the second largest national origin group in the city. It is also the fastest growing group; more than half belong to the second-generation, and more than $40 \%$ are younger than 19 years old (Crok et al.).

\section{SCHOOL OUTCOMES OF DOMINICANS IN NEW YORK AND MOROCCANS IN AMSTERDAM}

In the Netherlands, the Moroccan second generation is one of the poorest performing groups when it comes to education. In 2002, $17 \%$ of 15-34-year-olds were registered as leaving secondary school without a diploma (Herwijer, 2003). Second-generation Dominicans also have low levels of educational attainment compared with other ethnic groups. The Immigrant Second-Generation in Metropolitan New York (ISGMNY) study conducted between 1998 and 2002 found that 14\% of second-generation Dominicans in New York did not complete high school (Kasinitz, Mollenkopf, Waters, \& Holdaway, 2008). Both Moroccans and Dominicans have much lower educational attainment than native-born Whites; only $6 \%$ of native Dutch leave secondary school without a diploma, and fewer than $6 \%$ percent of White students in New York City do so. Whereas Puerto Rican students in the ISGMNY study have a higher dropout rate than Dominicans (19\%), the dropout rate for African American students is slightly lower. Other immigrant groups in the two cities also have higher educational attainment; the New York dropout rate was about $7 \%$ for South American students (with parents from Colombia, Ecuador, and Peru), 8.5\% for West Indians, and less than 5\% for Chinese students. In the Netherlands, only the Turks have higher dropout rates (21\%) than Moroccans. The other big immigrant group, the Surinamese, perform much better; only $11 \%$ are dropouts (Herwijer, 2003).

In terms of university attendance and graduation, Dominicans and Moroccans are performing at equivalent levels. By the age of 24, 29.7\% of Dominicans who graduated high school had obtained a bachelor's degree. This considerably exceeds the rate for native-born Blacks (20.7\%) and Puerto Ricans, and it is close to the rate for South Americans (30.8\%). However, it is far lower than that of native-born Whites, which is $64.5 \%$.

The number of students of Moroccan descent in higher education is growing fast. Postsecondary education includes both advanced vocational education (see the Discussion section) and university attendance. In 1995, only 15\% of 18-21-year-olds of Moroccan descent were registered as students in postsecondary education. In 2005, their number had more than doubled to $33 \%$ (Jennissen \& Hartgens, 2007). The majority (about $80 \%$ ) attend a higher vocational educational school (Crul \& Wolff, 2002). Moroccan students are more numerous than Turkish students (29\%) but are a smaller group compared with Surinamese (42\%) or native Dutch students (54\%).

It is also important to note that differences in the organization of higher education mean that these raw statistics are difficult to interpret. The U.S. postsecondary education sector includes a wide range of public and private 4-year institutions, in which the quality of education varies considerably, and 2-year community colleges, which provide more vocationally oriented programs. Although it is possible to transfer from community colleges to 4-year universities, this process extends the time to 
degree completion, and the majority of students do not transfer. Over a quarter of second-generation Dominicans in New York who attended college went to community college, compared with less than $10 \%$ of Whites and only about $15 \%$ of second-generation South Americans and West Indians. Furthermore, Dominicans who attended 4-year schools were attending institutions that ranked quite low in terms of selectivity and quality; only about $6 \%-7 \%$ went to universities ranked as National Tier I schools by the widely used U.S. News and World Report rankings, and another $10 \%$ or so went to a National Tier II school. About a quarter attended colleges ranked as Regional Tier II-mostly the stronger colleges of the public City University system-but another quarter went to weaker colleges in the public system or to private schools with poor reputations (ranked Regional Tier III or IV). In comparing the postsecondary educational attainment of Dominicans in New York with Moroccans in Amsterdam, it is therefore important to bear in mind that the quality of postsecondary education in the Netherlands is more uniformly high. At the same time, higher vocational programs in the Netherlands train students for careers for which at least a 2-year degree, and sometimes a 4year college degree, would be necessary in the United States. Although it is not possible to unpack this complicated comparison here, there appears to be some similarity between the role of higher vocational education in the Netherlands and that of community colleges in the United States.

\section{GENDER DIFFERENCES IN EDUCATIONAL ATTAINMENT}

Overall, girls and young women in both groups are doing better in school than boys. In contrast to young Moroccan men, second-generation Moroccan women have attracted favorable notice, and their educational performance has improved more quickly than that of men. Because women started from a lower position, until recently, they were only catching up. By now, they are bypassing men in secondary education and are entering higher education in higher numbers (Bijl et al., 2005). Girls of Moroccan descent are also more often found in preparation tracks for higher education than men (Herwijer, 2003) and are less likely to drop out of school (Turkenburg \& Gijsberts, 2006).

There are also noticeable gender differences among Dominicans. The high school dropout rate for Dominican boys in the ISGMNY study is higher (16.5\%) than the rate for girls (12.4\%), and women are more likely to complete college. Thirty-three percent of women aged 24 and older had completed a bachelor's degree compared with $27 \%$ of men. Boys are also more likely to be held back in school and to be put in special education classes. Nancy Lopez (2004) has argued that one of the reasons that Dominican girls do better in school is that they are often kept indoors, where they are often responsible for housework and care of younger siblings but are also more likely to do their homework. Young men are more subject to negative stereotyping from teachers and police, leading them to disengage from school. However, the ISGMNY study also found that parental protectiveness led girls to miss opportunities when parents did not allow them to travel out of the neighborhood to attend better schools and that parents' expectations for their daughters' achievement were generally lower. And, although Dominican women were more likely than men to attend university, they were more likely than men to go to weak institutions; the majority were concentrated in colleges ranked only in Tiers III and IV among regional schools.

Although they show higher educational attainment than boys, it is worrying that quite a high percentage of young women of both groups have children while in their teens and early $20 \mathrm{~s}$. If adequate financial and practical support is available, having a child does not always cause young women to end their education, but it generally makes it harder to continue and to complete each stage at the same pace as students without children. More than $12 \%$ of Dominican girls surveyed in the ISGMNY study had a child before the age of 18 , and $25 \%$ had a child by the time they were $21-$ the highest figures for any of the second-generation groups, though lower than the native-born Blacks and Puerto Ricans. A considerable proportion of women of Moroccan descent also marry young. In the age group 20-25, 45\% of the women are married (Distelbrink \& Hooghiemstra, 2006). Teenage pregnancies (15-19-year-olds) are not as common among Moroccan girls (around 1\%) as among Dominican girls (Distelbrink \& Hooghiemstra, 2006). However, it is worrying that those teenagers who do become pregnant are often without a partner, a fact that will seriously marginalize their position in the Moroccan community. Analysis of educational attainment shows that having a 
child young is a strong negative factor for both Moroccan and Dominican women.

Young men face different problems, particularly discrimination in public places and by the police. More than a third of all youngsters in frequent contact with the police in Amsterdam (between the ages of 12 and 17) were of Moroccan descent (Crok et al., 2004). Twenty-one percent of those surveyed in the ISGMNY study had been arrested, and 11.2\% had spent time in prison. A very high proportion of Dominican young men also said that they had experienced prejudice from the police.

Overall, we see some very similar patterns in educational outcomes of Dominicans in New York and Moroccans in Amsterdam, with the two groups also facing similar challenges as they face young adulthood. This is particularly interesting in light of the fact that the two contexts are so different, with the Netherlands pursuing a strong policy of integration and the United States following a more laissez-faire approach that leaves immigrant families to navigate the host society largely by themselves. So what factors are producing these outcomes? Before exploring the components of the context of reception in more detail, we first describe individual and family-level characteristics of the groups that could be relevant.

\section{BACKGROUND CHARACTERISTICS AND THEIR RELATION TO SCHOOL SUCCESS}

Clearly the resources that families have to support their children's education are important. These include the parents' level of education and income, the presence of adults in the home to provide financial and emotional support, and the quality of the neighborhood in which young people grow up.

The strongest predictor of educational success is the education level of the parents. Although different migration flows have created a community with a complicated class structure, Dominicans in New York have lower levels of education than most other migrants, including those from the Caribbean. According to the 1990 census, which is probably the most relevant for understanding the circumstances in which the second generation we are studying grew up, $60 \%$ of Dominicans had not completed high school, compared with $34 \%$ of Jamaicans, $35 \%$ of Haitians, and $53 \%$ of Cubans. The ISGMNY study found that $28.6 \%$ of fathers and $31 \%$ of mothers had only a junior high school education, and about $17 \%$ of parents had only grade school education (less than $2 \%$ had no formal education). Those Dominican parents (almost half of the group) who have only a junior high school or grade school education can help their children with homework in only a limited way. Many of them also have little proficiency in English, making it difficult to communicate with teachers.

Moroccan parents face even greater challenges. The vast majority of first-generation Moroccan men have completed no more than primary school or Koran school, and most Moroccan women had only a few years of schooling or are illiterate (Crul, 1994). This means that first-generation parents are not able to help their children with homework in any practical way. The language barrier also is a serious problem in communicating with teachers.

Financial resources are a second important indicator for success in schools. In general, we can say that limited financial resources are a bigger obstacle for educational success in the United States than in the Netherlands. As we see next, good education has a financial price in the United States, whereas in the Netherlands, tuition fees are almost never a serious issue.

Most Dominican families have few resources. Almost half of first-generation Dominicans entered the lowest segment of the labor market working as operatives and laborers (Grasmuck \& Pessar, 1991). Although some opened small businesses, many of these were undercapitalized and fragile and did not provide a secure financial basis for supporting a family. These patterns of employment, coupled with high rates of female-led households (almost $40 \%$ of Dominican households with children under 18 were female led) resulted in a high incidence of poverty (37\%) compared with $16 \%$ for the whole population, and 31\% for all Latinos (Pessar, 1995). 
Moroccan men primarily worked in factories, shipyards, or the cleaning industry before industrial restructuring in the 1980s put many of them out of work. Today, some $80 \%$ of the Moroccan male population aged 50 or older are outside the labor market. Because first-generation women rarely work outside the home, the majority of Moroccan families live on minimal incomes. Almost half indicated that they had financial problems in the last 3 months (Groeneveld \& Weijers-Martens, 2003), and many second-generation children grew up with fathers who were unemployed by the time they entered secondary school. However, as we see next, poverty has a larger impact on school choice in New York than in Amsterdam.

Both groups are known for their strong relationships with family and relatives in the home country. In addition to shaping identity, this strong transnationalism in both groups has implications for educational attainment in the second generation. First, the fact that one parent often migrated first means that some families were separated when the children were growing up, often causing tension and lack of communication within the family (Pessar, 1995; see also Levitt, 1991). At the same time, remittances may be an important source of support for relatives at home, but those funds are not available for investment in the future of the family in the United States or the Netherlands. In a context in which the quality of schooling received is highly dependent on neighborhood and in which rents and house prices in neighborhoods with good schools are high, both Dominicans and Moroccans are at a disadvantage relative to immigrant groups of similar socioeconomic status that concentrate their resources in the United States or the Netherlands.

The quality of schools, more so in the United States than in the Netherlands, is related to the socioeconomic status of the neighborhood and the degree of ethnic segregation-factors that sometimes, but not always, overlap. Dominicans are one of the most segregated communities in New York. In 1990, the Index of Dissimilarity from Whites (the percentage of a group's population that would have to move to achieve a residential pattern that reflects the group's percentage of the population in the city) was $82 \%$, and it had fallen only 2 percentage points by 2000 (Logan, 2002).

Moroccans are also the most segregated of all ethnic groups in Amsterdam, but segregation has a totally different flavor in Amsterdam than in New York. Not only is the segregation index from native Dutch (39\%) much lower (Musterd \& Deurloo, 2002), but neighborhoods are less dominated by a single ethnic group. However, the other large groups in these neighborhoods are often also immigrants (mostly Turkish). Together with the so-called White flight (Dutch-born parents sending their children to schools outside their own neighborhood), this segregation results in schools with a majority of children of immigrants. The quality of the schooling in these schools in general is lower than in other neighborhoods. Differences in quality, however, are not as great as they are in the United States.

The neighborhood is also important as the context in which children go to school. Both groups are concentrated in areas with a high crime rate. Neighborhoods in Amsterdam with a concentration of Moroccan inhabitants have become known for troublemaking youth. Reported crime rates show a dramatic overrepresentation of Moroccan adolescents and young men (Junger-Tas, Cruyff, van de Looij-Jansen, \& Reelick, 2003). The neighborhoods in which Dominicans settled, particularly Washington Heights, have become known for the prevalence of drugs, and although only a very small minority of the population is involved in the drug business, many more are affected by it. Forty-three percent of Dominican respondents in the ISGMNY study said that drugs were a problem in their neighborhood, and many complained about the pervasive stereotype of Dominicans as drug dealers.

The most difficult factor to link to educational success is discrimination. Both overt and institutional discrimination no doubt affect the school careers of both Dominican and Moroccan youth, shaping their educational careers and their future prospects. Many Dominicans in New York face discrimination because they are dark-skinned. Although many first-generation Dominicans resist being identified as Black, which they see as a characteristic of Haitians, this does not change the fact that many other people regard them as Black (Itzigsohn \& Dore-Cabral, 2000; Lopez, 2004; Pessar, 1995). Although the first generation may maintain premigration identities, the second generation 
must navigate the racial/ethnic politics of New York. Survey data from the ISGMNY study show that after native Blacks and West Indians, Dominicans are most likely to say that they had been discriminated against by the police and in public spaces.

In contrast, Moroccans in the Netherlands are more likely to feel that they are discriminated against because of their religion. Although most second-generation youth do not practice their religion actively, they still have strong feelings about it. Tolerance toward the Muslim population among the native-born Dutch population has declined dramatically in the last 5 years, and there is a strong negative discourse about Muslims in the media that has also gained considerable political support. Figures indicate that Moroccan youth, especially Moroccan boys, suffer the most discrimination of all visible ethnic minority groups in the Netherlands, in the labor market, and also in public spaces. In a recent study, $50 \%$ of Moroccans reported serious incidents of discrimination or racism in the last year (Boog, Donselaar, Houtzager, Rodrigues, \& Schriemer, 2006). That is twice as high as among the Surinamese Dutch, who are of African or Indian descent. Among the younger cohort, the percentage goes up to $70 \%$. A third of Moroccans who went for a job interview in the last year were sure that discrimination was the reason that they were not chosen for the job, and a quarter suspected it (Boog et al.). When calling for a job interview, Moroccan pupils with a middle vocational education had a 30\% less chance of being invited than native Dutch pupils (Boog et al.).

As we have seen, despite some important differences, the social situations of Dominicans and Moroccans are similar in many ways. Children in both groups grow up in poor households in highly segregated neighborhoods, and their parents have low levels of education. For different reasons, men of both groups experience high levels of discrimination.

In this sense, providing an education that will enable the Moroccan and Dominican second generation to move out of poverty presents a similar challenge in both countries. In the next section, we consider differences in the structure of the education system in the two cities and analyze the ways in which it shapes the educational trajectories of the two groups. It is interesting to see how the two groups are sorted in different ways through the school system but with almost the same outcomes.

\section{THE ROLE OF SCHOOL SYSTEMS IN EXPLAINING EDUCATIONAL OUTCOMES}

Children of Moroccan and Dominican families enter school systems in the two cities that differ considerably both in their overall structure and in their specific policies toward children of immigrants.

One of the pillars of the Dutch educational system has always been the freedom to choose the school of one's own religious or ideological preference without extra cost. All schools teach the same curriculum, and school fees are very low or nonexistent. But although in principle, immigrant parents can send their children to a primary school in an upper-class neighborhood without additional cost, in practice, they generally send them to schools in their own neighborhood. Most Moroccan parents do not send their children to schools in better-off neighborhoods because they usually do not have information about them. ${ }^{1}$

Another important characteristic of the Dutch school system is the extra funding that primary schools receive for children of immigrants. Since the 1980s, primary schools with many children of immigrants have received extra funding under the Educational Priority Policy. Schools get nearly twice the sum of money for a child with an immigrant background as they do for a child of nativeborn parents from a middle- or upper-class background. Through this mechanism, hundreds of millions of euros have been invested in primary school education for the children of immigrants over the last 25 years (Crul \& Doomernik, 2003).

A pupil officially enters primary school in the Netherlands when he or she turns 4 . Primary school 
consists of eight grades, so children usually leave at age 12. At the end of primary school, all children have to take a national examination that is crucial for their further school career in secondary school. On the basis of this test result and the recommendation or "advice" of their teacher, they will be assigned to different tracks in the secondary school system.

Prevocational Secondary Education (VBO) is the lowest and least attractive stream of secondary education, and it is where children with the lowest advice from primary school end up. Children with a Junior General Secondary Education (MAVO) advice or higher usually go to comprehensive schools that have three streams: Lower General Secondary Education (MAVO), and two streams preparing children for tertiary education: Senior General Secondary Education (HAVO) or Preuniversity Education (VWO). In the first 2 years of comprehensive school, all children study together regardless of their school advice from primary school. ${ }^{2}$ This means that selection for most children is postponed for 2 years, and there is the possibility for some to move up to the more prestigious streams (HAVO and VWO) during this time. ${ }^{3}$

Most children continue to study after they have gained their secondary school diplomas. The children who have a VBO or MAVO diploma will continue in middle vocational education (MBO). This could mean a 2-, 3-, or 4-year course, either full time or part time. A 3- or 4-year course gives students the right to continue to higher vocational education, but most students take shorter courses and leave school to look for a job. Pupils with a HAVO diploma can continue to go to higher vocational educational school, and pupils with a VWO diploma go on to university.

Another characteristic of the Dutch school system is that pupils can easily move from one stream to the other. In principle, one could start at the bottom and move up step by step to the highest stream, taking what is called the "long route" through the educational system. It takes between 1 and 3 years longer, but many children of immigrants have moved up the educational ladder in this way. There are, it is important to emphasize, no financial penalties for taking the long route.

In New York, the education system is characterized by extreme variation in the quality of schools. Residential segregation and the underfunding of urban schools have been the subject of considerable attention in the U.S. literature (e.g., Anyon 1997; Kozol 1991), and recently, research has begun to focus on where the children of immigrants fit into this picture. The ISGMNY study shows that patterns of residential settlement and different levels of parental information regarding schools mean that the children of different immigrants attend widely different schools, as we discuss further in this article (Kasinitz et al., 2008).

The diversity of educational provision is accompanied by a lack of formal tracking mechanisms or a clear connection between educational programs and the labor market (Rosenbaum, 2001). Children begin school at age 6 (though many attend preschool before that), usually attending elementary school in their neighborhood. From there, they move to middle school at age 10, and then to high school at 14. Although high school continues until age 18, legally required education in New York State ends at age 16, and some students leave early with or without a diploma.

Until the end of high school, when students who plan to attend college generally take the SAT Reasoning Test, there is no uniform national test that measures attainment, and the quality of education offered in different high schools varies considerably. Although completion of certain courses, including honors and Advanced Placement courses, will improve students' chances of college acceptance and success, the high school diploma itself (as well as the General Educational Development [GED] diploma, which can be earned after or outside high school) is undifferentiated. Although obtaining these diplomas opens up the path to higher education, students who fail to graduate are generally left with no qualifications at all (Kerckhoff, 1995). New York does have a number of vocational high schools that prepare students for particular careers, but the majority are comprehensive schools. There are also a few highly selective "magnet" high schools and programs within schools, that students must take a test to enter. Thus, although tracking methods are much 
more informal than in the Netherlands, as we will show in the more detailed discussion that follows, students are still effectively channeled from a very young age onto very different and unequal educational trajectories.

\section{QUALITY OF PRIMARY EDUCATION}

Although there is freedom of school choice in the Netherlands, most Moroccan children ended up in highly segregated schools in Amsterdam. This was the result of Moroccan parents choosing schools in their own neighborhood. In general, first-generation parents had little information about the quality of schools in Amsterdam. In addition, many of them had little formal schooling themselves and could barely speak Dutch.

The typical career of Moroccan pupils is closely connected with problems in inner-city primary schools with many children of immigrants. Because of the concentration of immigrants in certain neighborhoods, a few schools were responsible for absorbing a great many children of immigrants (including both Moroccans and children of Turkish immigrants) in a short period of time. Over a 58-year period, primary schools in Amsterdam neighborhoods like Indische buurt, de Pijp, Bos en Lommer, and Baarsjes changed from having a mostly native Dutch clientele to having a predominantly Moroccan and Turkish student body. Whenever the number of children of immigrants passed 40\% Dutch, parents started to avoid these schools. This "White flight" accelerated the concentration of children of immigrants. ${ }^{4}$ Freedom of school choice thus provided Dutch parents with the opportunity to escape schools in their neighborhoods with many children of immigrants, but local policy makers did not act on this for a long time because they feared that forced mixing would cause them to lose votes from the native Dutch population.

When policy makers finally took action, it was already too late. At the end of the 1990s, almost all the inner-city neighborhoods adopted a policy that allowed parents freedom of school choice only within their own neighborhood. Although this was intended to stop White flight, this is not what happened. Either Dutch parents found a way around it, or they moved out of neighborhoods with a high concentration of immigrants. The result was that neighborhood schools were becoming more, rather than less, concentrated, and at the same time, immigrant parents could no longer send their children to schools outside their own neighborhood. In the end, then, the combination of demographic change (more than half of children under 12 in Amsterdam are now from immigrant backgrounds) and residential segregation has resulted in a great number of schools with $70 \%$ or more children of immigrants. In an increasing number of schools, there are no children of native Dutch parents.

Especially in the 1980s, when schools were confronted in a short period of time with a large influx of pupils of Moroccan and Turkish descent, schools were unable to provide sufficient help and support to their pupils. During this period, most of these primary schools developed ad hoc policies and were basically in a state of crisis management. Teachers complained that it was impossible to teach adequately because of the wide variation within the classes in terms of age, abilities, and years of Dutch schooling (W. de Jong, 1986). Schools with a high concentration of children of immigrants still perform worse even after adjustment for parental socioeconomic status, although the difference has decreased. Quality differences show up in mathematics and language scores. The poorer quality of "immigrant schools" is partly a consequence of lower standards applied to migrant pupils there. Because teachers know by experience that many pupils cannot handle the full study load received by the children of Dutch parents, they consciously or unconsciously lower their standards. The mechanisms involved here were reported by the national education inspectorate, which monitors schools on a regular basis.

Alarmed by numerous reports about the problems in primary schools, the government in 1985 launched the so-called the Educational Priority Policy. The cornerstone of the policy was support for primary schools with a high percentage of immigrant children, which would receive almost twice 
(1.9 times) as much funding for each immigrant child compared with a middle-class or upper-class native Dutch child. The extra funding in the first years of this policy change was spent mostly on creating smaller classes, but this did not bring the results hoped for (M. de Jong, 1997). The idea was that the teacher would be better able to provide individual help and support, but the percentage of immigrant children in these schools continued to rise to the point at which more than $70 \%$ of children in some schools were from immigrant backgrounds. In practice, this means that 10-15 of the 20 pupils in any given class had learning difficulties. Although the teacher would not have to teach 30-35 pupils, as in other primary schools, it was still impossible to give individual attention to each child.

Slowly, the schools also found out that second language acquisition was not the only problem. The class background of the immigrant parents posed equally big challenges. The children were often the first in the family to go to school. Many parents did not have any experience of going to school themselves, so they were often unable to help their children practically. Language and cultural barriers also made contact between parents and teachers problematic. A major complaint from teachers in the 1980s and 1990s was that Moroccan and Turkish parents seldom came to teachers' contact evenings and were generally less involved in the school careers of their children.

Schools increasingly started to focus on new teaching methods, especially those aimed at second language education. The new teaching methods and books were financed with extra grants from the city of Amsterdam (made available to the larger cities through the national budget). As a result, conditions in schools with many children of immigrants have improved. The classes in these schools are smaller now (10-15 fewer pupils than in a class with $70 \%$ or more children of native Dutch parents), and they often have an extra teacher assistant, the newest teaching methods and books, and the best facilities in terms of classrooms and available space.

This has resulted in gradually improving results for most children of immigrants in these schools. National test scores at the end primary school show that children of immigrants slowly are closing the gap with children of native-born parents. In 8 years (1994-2002), Moroccan pupils managed to close $30 \%$ of the gap with native-born Dutch on the national test (Gijsberts \& Hartgers, 2005). With the extra funding that allows for smaller classes and a curriculum that focuses on the special (language) needs of children of immigrants, the schools have found a recipe that works.

The better results in primary school lead to more Moroccan pupils going to intermediate classes that would give them a chance to continue to HAVO or VWO. If we compare the position of Moroccan pupils in the 3rd year of secondary school in 1995-1996 and in 2001-2002, we see a more than twofold increase (of $11 \%$, from $8 \%$ to $19 \%$ ) over 6 years in the more prestigious levels HAVO and VWO (Herwijer, 2003), which give access to higher education. More and more Moroccan pupils were able to avoid early selection at the end of primary school and, as a consequence, did not land on the vocational track.

Children in the United States enter kindergarten at age 5 and move into first grade the next year. Despite efforts to introduce greater choice, the quality of K-6 grade schools, as primary schools are called in the United States, is still largely determined by where one lives. New York City has 32 community school districts, each of which is divided into zones, and students go to their zone school unless their parents apply for a waiver, which is known as a "variance" (Cookson \& Lucks, 1995). Although they are part of the same unified school district and receive the same funding (an average of $\$ 9,621$ per pupil in 2000) conditions, the quality of education in these local schools varies enormously, and these differences in quality overlap with patterns of residential concentration. For example, data from the New York City Board of Education shows that the percentage of elementary and middle school students performing at grade level in English in 2001 ranged from as low as $26 \%$ in the predominantly Black and Latino Highbridge/South Concourse neighborhood of the Bronx, to $76 \%$ in the Bayside/Little Neck area of Queens, where residents are mostly White and Asian. There was a similar range for student performance in math. Low-performing schools have worse facilities and higher percentages of teachers who are uncertified or not qualified to teach the class subject 
(Mei, Bell-Ellwanger, \& Miller, 2002).

The bulk of funding for education in the United States comes from the local and state level. In New York City, $47 \%$ comes from local sources, $43 \%$ from New York State, and the remainder from the federal government. In the city's budget, education must compete with other services for funds, so it is not constant, but subject to political debate. Because the city forms one unified school district, individual schools are not in competition with each other for funds (which they receive on the basis of enrollment). However, they do compete with each other, and with better funded suburban schools, for qualified teachers and administrators.

Most of the support for children of immigrants in the United States has taken the form of language education. Although some states introduced formal instruction in the home language of immigrants - particularly German — as early as the 1830s, and many others provided dual-language instruction on an informal basis, bilingual education was more or less abolished during World War I. It reappeared only in the context of the civil rights movement in the 1960s and when a new influx of immigrants made it clear that it was not possible to leave them to "sink or swim" in English-only classrooms. The Bilingual Education Act of 1968 provided federal funds to encourage states to provide some form of dual-language instruction for immigrant students, and following a Supreme Court ruling and several lawsuits at the state level, the Equal Educational Opportunity Act was passed in 1974, mandating schools to overcome linguistic barriers for students' equal access to the curriculum. This legislation did not, however, stipulate how this should be done, and debate has subsequently raged over the role that the native languages of children of immigrants should play in schools.

Whereas other states have pulled back from bilingual education, New York continues to maintain a comprehensive program, with most of the city's schools offering some kind of bilingual or English as a second language (ESL) program. If students entering school score lower than $41 \%$ on the Language Assessment Battery test, they are designated English language learners (ELLs) and are obliged to enroll in either bilingual or ESL classes until their score is over the cutoff point.

Elementary schools that have more than 15 ELL students over two consecutive grades are required to create a bilingual program in that language (for high schools, it is 20 students). Bilingual programs include short-term transitional programs that aim to transfer students to English as soon as possible, maintenance bilingual programs that aim to develop academic proficiency in both English and the parents' language, and dual-language programs that include both ELL students and native English speakers. In New York, 60 schools offer dual-language programs, mostly in Spanish. ESL programs, which are taught in English, are more common. The current cost of bilingual programs for the city school system is \$45.6 million, and for all ESL programs is almost \$123.3 million (New York City Board of Education, 2001). Despite this level of investment, more than one quarter of the system's 4,057 bilingual teachers are not certified, and even fewer are specifically certified as bilingual or ESL teachers. Funds for bilingual education come from the state. Another source of additional funds comes from the federal government in the form of support for supplementary programs under the Department of Education's Title I. These funds are disbursed to school districts based on the number of low-income families identified in the census. Their use is determined by school boards and includes after-school programs, tutoring, parent information, and training. The use of funds is determined by an advisory council, which includes at least five members who are elected by parents.

The funds available to any given school in New York City will therefore depend on the number of students enrolled and also on the percentage of students who come from low-income families. Additional funds may also be raised from charities and foundations that support educational programs. These contributions can range from small parental initiatives to substantial contributions from large foundations like the William B. Gates Foundation, the Rockefeller Foundation, and the Carnegie Corporation of New York. Although they sometimes support more sweeping reform, foundation contributions are often targeted toward after-school and other supplementary programs for disadvantaged students. Although schools may apply for funds directly, they are also often channeled through community-based organizations that provide services to particular populations, 
including immigrants. Therefore, although there is no official support for children of immigrants as there is in the Netherlands, some targeted programs do exist. For example, the Alianza Dominicana, the largest community-based organization serving the Dominican community in New York, runs a number of after-school programs that serve a primarily immigrant student population.

Because Dominican families are so residentially concentrated, their children generally attend schools with high numbers of ELL and low-income students. In the ISGMNY study, 16\% of Dominicans born in United States, 24\% of Dominicans who arrived between the ages of 1 and 6, and 62\% of those who arrived between the ages of 7 and 12 were in ESL classes. Although Dominican respondents who grew up in more mixed neighborhoods in Queens reported going to school with students from many different backgrounds, those who grew up in Manhattan or Brooklyn attended school mostly with other Latinos and native Blacks.

Of course, segregation is an old problem in U.S. education. Established after the abolition of slavery as a way for Whites to preserve social distance from freed Blacks (Massey \& Denton, 1993), segregation policy was upheld thereafter by the Supreme Court decision in Plessy v. Ferguson in 1896, which ruled that "separate but equal" facilities, including schools, were constitutional. The landmark case Brown v. Board of Education in 1954 undermined the legal basis for separate schools but did not resolve the problem of how to integrate them. In the early 1970s, court-ordered bussing in many states met with fierce opposition from White populations, fueling their move to the suburbs, and by the 1990s, the policy of achieving integration by bussing students to schools that were not in their neighborhoods ended in most cities. More recent efforts to bring about equity in education have focused on funding and the quality of education provided rather than on the race and ethnic mix of the students. Increasingly, parental choice rather than equity is the goal. Without explicit efforts to stop it, and with residential concentrations continuing to underpin it, school segregation has been on the increase in many states (Orfield \& Yun, 1999), creating growing numbers of schools with high concentrations of low-income, and often ELL, students.

Efforts to introduce greater school choice in New York have been stymied because there are too few places in good schools - one group of researchers estimates that there are up to 30 applicants for every seat in the better schools - and the city does not provide transportation for students who live far away (Teske, Schneider, Roch, \& Marschall, 2000). But studies have shown that many immigrant parents lack information about these alternatives anyway, and, with the exception of the Chinese, few take advantage of opportunities to send children to school outside the neighborhood (Kasinitz et al., 2008; Lipsit, 2003).

\section{TRACKING IN SECONDARY EDUCATION AND POSTSECONDARY EDUCATION IN THE NETHERLANDS AND IN MIDDLE AND HIGH SCHOOLS IN THE UNITED STATES}

Because children of Moroccan and Dominican immigrants are often unable to catch up with more advantaged students in primary school, they are behind at the point of selection into secondary school. In the Dutch system, this is a very clear turning point in a student's school career. At the end of their primary schooling, about a third of the Moroccan pupils are tracked into the lowest streams of secondary education (VBO). Many boys get a recommendation from the school (known as "an advice") for a technical school, and many girls are directed to a vocational school for housekeeping or tailoring. This means that they are not able to go to an intermediate class in secondary school and are sent directly into the vocational stream. By age 12, their future school careers are already pretty much determined.

The concentration of children of immigrants in vocational schools in Amsterdam has increased rapidly in the last 5-10 years, and the same problems faced by the primary schools can now be found in vocational schools. These schools also have the additional burden of educating immigrant children who have just arrived in the Netherlands between the ages of 12 and 15. Dropout rates in the vocational schools are very high, and the school climate is not very conducive to school success. 
Another third of second-generation Moroccans in Amsterdam enter Lower General Secondary Education (MAVO) directly after primary school, or after 2 intermediary years. The school climate in MAVO is considerably better than in VBO. The likelihood that a Moroccan child will drop out of school without a diploma are $31 / 2$ times higher in VBO than in MAVO (Tesser, Merens, \& van Praag, 1999).

After VBO or MAVO, almost all Moroccan pupils go on to middle vocational education (MBO). A small group continues at HAVO (the preparation track to higher vocational education). In MBO, they can be placed in short tracks of 2 years, or they are given access to the 3-or 4-year tracks. The 2-year tracks (KMBO) are especially designed for those who finished VBO on the lowest level or who left secondary school even without a VBO diploma. About $40 \%$ of the pupils of Moroccan descent who follow MBO are to be found on these short tracks (Jennissen \& Hartgens, 2007). Almost as many KMBO pupils leave school without a diploma as with a diploma, and dropout rates are extremely high. The short track most often leads at best to unskilled jobs, but more often to longterm unemployment.

About 25\% of the pupils of Moroccan descent in MBO follow a 3-year track that gives them access to skilled blue- or white-collar jobs (Jennissen \& Hartgens, 2007). Most pupils with a MAVO diploma continue to go on to a full 4-year MBO track (about $25 \%$ of the pupils of Moroccan descent in $\mathrm{MBO}$ ). A diploma from a full 4-year MBO track gives them access to higher vocational education. A considerable portion of this group of 4-year MBO students continues to go on to higher vocational education. By taking this route, they have to study 2 years more than via the direct route through HAVO. This is the "long route" to higher education (see Figure 1), and only those who are very persistent will be able to follow it to the very end.

\section{Figure 1. Organization of the Education System in the Netherlands, 2006-2007}

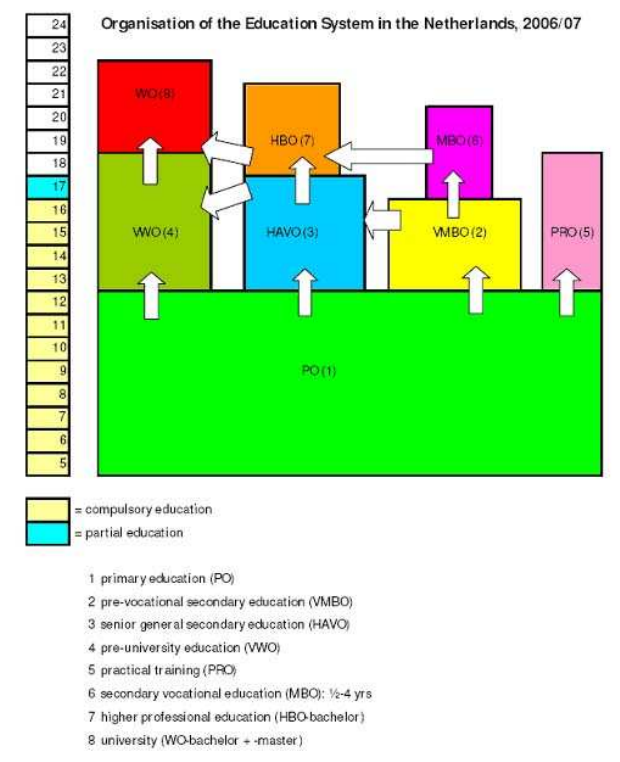

click to enlarge

*SOURCE: EURYDICE: The educational system in the Netherlands 2007, by the Ministry of Education, 2007, The Hague, Netherlands.

Students in the United States face a secondary school system in which the tracking is much less formal (Figure 2). Usually, they transfer to middle school after sixth grade and move again to high school after ninth grade, at the age of 14. Middle schools, or junior high schools as they are also called, were introduced shortly before World War I. In addition to providing the last few years of education to those who then left for the labor market, they also had the goal of sorting the students who were continuing their education into the two high school tracks available at that timevocational and college preparatory. Now most high schools are "comprehensive," and tracking takes place within them. However, sorting by ability already takes place in most middle schools, in the 
form of "smart" classes or special programs for "gifted and talented" students (Oakes, 1985). Middle schools, which also rely on residential catchment areas (but larger ones than grade schools) also vary widely in their quality, which is crucial in determining the type of high school students can hope to gain entry to.

\section{Figure 2. Structure of Education in the United States}

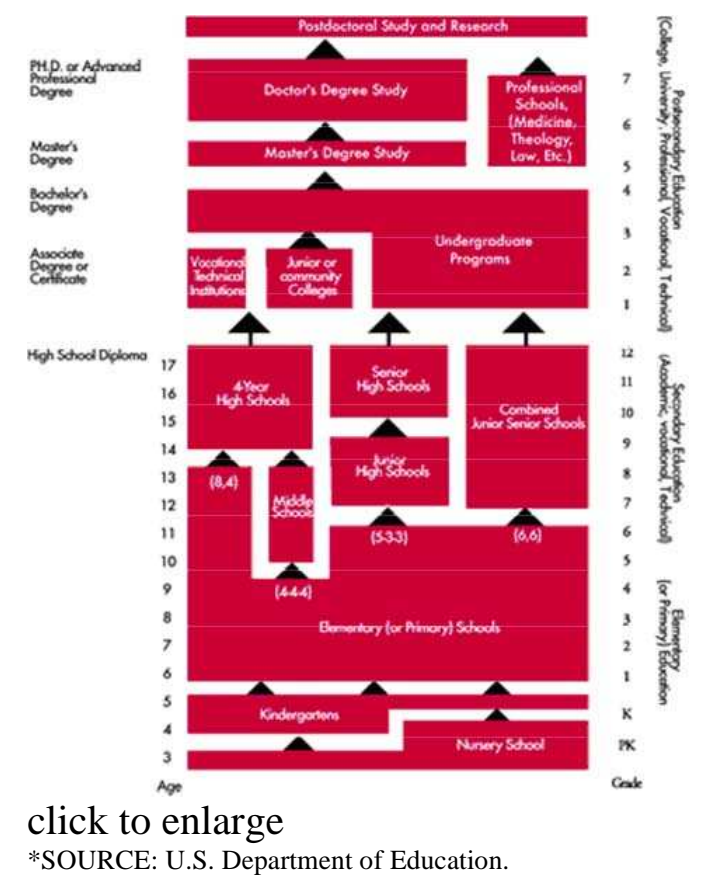

Although most New York high schools are "comprehensive," students can take a test for entry into one of five magnet high schools. These schools provide an enriched curriculum, and some are more selective than Ivy League colleges. Selective magnet and specialized programs are also available at certain other high schools. However, few students who attend weaker grade and middle schools pass these highly competitive tests. If their parents cannot afford private or parochial school fees, they will then go to local zoned high schools that are of extremely varied quality.

Although there is no formal hierarchy among the city's "general" high schools, they differ enormously in terms of all measures of quality and performance, and the worst of them are very bad indeed. In 2000, 68\% of New York high schools had lost $50 \%$ of freshmen by senior year, and $81 \%$ had lost $40 \%$ (Balfanz \& Letgers, 2004). ${ }^{5}$ More than 30 high schools had extremely low retention rates of $30 \%$ or less. These schools are fed by weak middle schools; more than $20 \%$ of ninth graders enter these high schools over age, and less than $20 \%$ of them have met eighth-grade standards in English and math. Over half of the teachers hired by the New York City Board of Education leave within 5 years, and the preferences given according to seniority mean that more experienced teachers can easily transfer out of bad schools, leaving the most disadvantaged students with the unqualified teachers.

The in-depth interviews conducted as part of the ISGMNY study show that Dominican parents often had high aspirations for their children, hoping that they would be the first in the family to attend college. But many lacked the information to steer their children through the lower reaches of the education system. Other studies have also found that immigrant parents are poorly informed about the options available to their children (Lipsit, 2003).

Because of limited information networks, most Dominican families seem not to have been aware of the specialized high schools that provide a route of upward mobility for some other immigrant groups, most notably the Chinese (Kasinitz et al., 2008). Fewer than half of the Dominican ISGMNY respondents said they knew about the schools, and very few took the test. Even when their children 
did take the test and passed, Dominican parents did not always realize what a difference it would make for the children to attend a magnet school. In some cases, parents refused to allow their children to travel to better schools outside the neighborhood, fearing for their safety. In other cases, young people themselves felt uncomfortable about going to schools that were predominantly White and Asian, feeling that they would not fit in.

Overall, the Dominican second-generation are very disadvantaged in terms of the secondary schools they attended. Sixty percent of Dominicans in the ISGMNY study attended schools in the lowest two quintiles in terms of performance, ${ }^{6}$ compared with about $40 \%$ of West Indian second generation, $50 \%$ of native Blacks, and 55\% of Puerto Ricans. Dominicans attended worse schools than others even when parents' level of education and other factors are controlled for. Only $6.2 \%$ were attending schools in the top tier, the lowest of any group in the study, and not a single Dominican respondent attended one of the three most selective public schools in the city: Stuyvesant, Bronx Science, or Brooklyn Tech. Of those who went to top-tier schools, a third went to a limited number of relatively less prestigious schools in that category. Dominicans who grew up in the Bronx and in Manhattan were most likely to attend bad schools (over $56 \%$ of those who spent most of their childhood in the Bronx went to schools in the lowest quintile, and $44 \%$ of those in Manhattan, compared with only $23 \%$ of those who grew up in Brooklyn and $8.2 \%$ of those who grew up in Queens).

Those who ended up in "bad" high schools talked about ethnic tensions and gang fights, which aggressive surveillance by security guards - itself a source of discomfort for many students-did not seem to prevent. In some cases, the violence was so extreme and pervasive that students stopped attending school, but many young men were also drawn into it in an effort to defend or prove themselves. Complaints about teachers who were indifferent or even hostile to their mostly minority students were common, and many students routinely cut classes.

\section{THE ALTERNATIVE ROUTE THROUGH CONFESSIONAL SCHOOLS}

A minority of successful Moroccan students, by their own choice, went to primary schools in Amsterdam where there were few other immigrant children. At that time, this often meant a school with a special pedagogy (often a Montessori school) or a Protestant or Catholic school. The Moroccan children in these schools quickly picked up the Dutch language and were exposed through their relationships with Dutch peers to the "Dutch" way of interaction between children and between children and teachers (Crul, 2000). Teachers often gave the only Moroccan child in the class extra help and support and, as a result, many did well and were recommended to go on to the more prestigious secondary tracks (HAVO or VWO). There they were again in classes with native Dutch children and benefited from high expectations and support not found in schools with high percentages of children of immigrants.

Dominicans in New York also turned to religious schools-primarily Catholic schools-as an alternative as much because they thought educational standards would be higher and the discipline stricter as for the religious instruction that they provide. But Catholic school is expensive, especially for high school, with fees in the range of $\$ 5,000$ a year, and this was a considerable burden for lowincome Dominican families. Although about a third of Dominicans in the ISGMNY study reported attending Catholic school for at least a year, only $12.7 \%$ graduated from Catholic school or were still attending at the time of the survey, indicating that for many families, this is not an affordable alternative to public school. In the in-depth interviews, respondents talked both about financial pressures, as well as sometimes being expelled from Catholic schools for low grades or disciplinary problems (see Louie \& Holdaway, 2009).

For reasons that are not entirely clear, Catholic school does not seem to have had as beneficial an effect on Dominican children as it does for other groups, including other Latinos. This may be because they attended less academically oriented Catholic schools; the quality varies considerably from those with admissions tests and advanced courses to those with open admissions and a more 
basic curriculum. Although the numbers involved are not large enough for statistical analysis, it is clear that there is also segregation within the Catholic system and that Dominicans were not generally attending the same Catholic schools as Whites (Louie \& Holdaway, 2009). Furthermore, Dominican students who left Catholic school often went back into the weaker schools of the public system from which their parents had been trying to save them in the first place, whereas Chinese and West Indian parents, for example, were able to use the Catholic system strategically to position their children for entry into the higher echelons of the public school system.

\section{DOMINICAN AND MOROCCAN STUDENTS AND THEIR ROUTES TO SUCCESS}

Between their own limited resources and the challenges presented by the school systems in the two cities, Moroccan and Dominican families both face significant difficulty in getting their children a good education. So what is distinctive about the school careers of those students who do manage to succeed despite these obstacles? An examination of the factors behind successful Moroccan students in Amsterdam schools highlights three positive characteristics of the Dutch educational system (Crul, 2000). The first is the route through confessional schools made possible by the free choice of schools discussed previously. The fact that religious schools in the Netherlands are free is also a factor.

The second route to success was through intermediary classes (ages 12-13) in secondary school. Moroccan children who went to comprehensive schools (even when they only had an advice for lower general secondary education) had 2 more years to catch up, and many did. After 2 years, they were able to move up to the preparation track for higher education.

The third route, which was taken by a considerable group of Moroccan second-generation children, was the so called long route. These children moved up step by step to higher education, first going to lower general secondary education, then higher general secondary education, and then to tertiary education.

Examining the pathways taken by successful Dominican respondents in the ISGMNY study shows that both familial and institutional factors made a difference. As discussed, one of the main ways that families tried to avoid the worst public schools was to send children to Catholic school, and several successful respondents had attended Catholic school the whole way through. But because religious schools in the United States cannot receive public funding, this required significant expense on the part of parents and was possible generally only for those families in which both parents were working.

Other successful respondents were able to access better public schools even though their parents often did not have much information. Those who lived in less segregated, generally middle-class, neighborhoods had access to better local schools. In other cases, the help of teachers and guidance counselors was crucial in steering students toward educational opportunities. Several respondents explained that their teachers encouraged them to take the test for the selective high schools or travel out of the neighborhood to a better school Families also learned over time that they could not assume that their children would receive a good education at the local school and often made different choices for later children than for the eldest.

\section{ACCESS AND OUTCOMES FOR THE TWO GROUPS}

The two cases make an interesting comparison. Although very different, both the New York and the Amsterdam cases show how differences in educational attainment begin with segregation in primary school, which makes it difficult for the children of immigrants to access the higher levels of the education system later.

This similarity persists despite the differing funding situation of schools in these cities. In New York, schools in immigrant neighborhoods usually are underfunded and understaffed compared with the 
suburban schools attended by most native-born White children. In Amsterdam, however, schools with many children of immigrants have higher budgets than schools that children of privileged families attend. They have more staff, smaller groups of children per class, and usually the best facilities. But this still does not make them the best schools. In terms of output, these schools still lag considerably behind schools where a majority of students are children of Dutch parents. The human capital of the children (from middle- and upper-class families) makes them into better performing schools even when their financial resources are much lower; the additional funds are simply not enough to meet the additional needs of children of immigrants.

At the same time, the higher resources in schools with a majority of children from immigrant parents do make a difference. A steady rise in their school results is slowly closing the gap with the results from children of native-born parents. Although children of immigrants in Amsterdam have not caught up, the comparison suggests that the infusion of funds is worthwhile and should, if anything, be increased.

The combination of the freedom to choose the school, and the extra funding helps to increase social mobility within the Dutch system. Like working-class children, children of immigrants have profited from these positive characteristics of the Dutch educational system. However, the more favorable picture for children of immigrants in the Netherlands in primary school is, however, followed by a less favorable picture in secondary school. Because they are still behind native-born children at the point of selection for secondary school, children of immigrants generally still end up in the lower streams of the secondary system, with little chance of changing to a more academic track later. Tracking in secondary school in Amsterdam is far more selective and rigid than it is in middle school and high school in New York; the American school system offers more possibilities for movement up the educational ladder after primary school and for second chances, even in postsecondary education. But the difference should not be exaggerated. As we have seen, the poor quality of primary and middle school education received by many Dominican students means that they are generally unable to test into the most prestigious schools in the New York system and are concentrated in the weaker high schools from which their chances of graduating and attending college are much lower. In addition, the quality of colleges they attend is generally low, and attending these schools is not necessarily better preparation for the labor market than the higher levels of vocational education in the Netherlands.

What conclusions can we draw from this analysis? First, although tracking in one system is clear and in the other less evident, both systems effectively channel students at quite a young age onto educational pathways that lead to very different outcomes. For the children of immigrants, early tracking that sorts children before they have had the chance to catch up puts them at a disadvantage compared with native-born children.

If high school education is to be so stratified and tracking does happen early, the quality of primary school education is extremely important, and it is crucial to ensure that families can secure a decent early education for their children. On the policy level, money spent wisely on reducing class size, in combination with appropriate curriculum and materials, helps children of immigrants catch up. But as the Netherlands case shows, it takes intensive interventions to really make a difference, and this is difficult in schools with many students from immigrant families.

One of the problems is that a small number of schools in low-income neighborhoods end up bearing the brunt of the responsibility for educating the children of poor immigrant families. Residential segregation and the concentration of children of immigrants in these schools make it harder to give them the basic education they need. But the U.S. experience with bussing and the Netherlands experience with zoning restrictions show that segregation is very hard to overcome. White parents will try very hard to circumvent efforts to integrate schools, and immigrant parents are often wary of sending their children to schools outside the neighborhood. This implies that either sufficient resources have to be pumped into minority schools to compensate for the difference or that majorityminority schools somehow have to be made appealing to White parents. This has generally been 
attempted with internal tracking.

In considering ways to address these problems, we need to know more about how families and communities try to get their children better education and what works. How aware are they of the problem, and what do they do about it? Do they try to access better schools within the system, turn to religious or private education, find ways to supplement the education their children get in public schools, or lobby for reforms that will improve the schools they have?

We can also learn from the experience of successful students. Looking at the factors-at home, at school, and in the community - that have enabled some students to succeed in spite of discouraging circumstances may tell us something about the ways in which we can support more of them to do so. Finally, the comparison highlights the question of gender differences. Given that boys and girls from the same families often attend the schools but girls seem to do relatively well, we need to know more about the family, school, and neighborhood dynamics that make this possible, and how the various people in students' lives-parents, teachers, community workers - can do a better job of helping them to overcome the difficulties they face.

Notes

1. About 5 years ago, zoning was introduced in Amsterdam to stop the White flight from neighborhoods with a large immigrant population. However, this also prevents immigrant parents from sending their children to less segregated schools.

2. Over the last 5 years, Amsterdam schools have increasingly separated children in separate MAVO streams, MAVO/HAVO streams, and HAVO/VWO streams. This means that pupils have less chance to stream up in the first 2 years.

3. Over the last 5 years, the two intermediate years have been abolished by most schools in Amsterdam.

4. Initially, Dutch parents sent their children to Montessori schools or Catholic or Protestant schools in their neighborhood to avoid schools with many children of immigrants, but as immigrant families increasingly began to choose these schools too, the native Dutch started to send their children to schools outside of their own neighborhood.

5. The lack of national comparative data makes it impossible to calculate actual high school dropout rates, but Balfanz and Letgers (2004) used the percentage of the entering freshmen class still enrolled in their senior year as an approximate equivalent for assessing the "promotion power" of high schools.

6. Measured on a scale that includes the percentage of students performing at grade level, teachers qualifications, and so forth.

\section{References}

Anyon, J. (1997). Ghetto schooling: A political economy of urban educational reform. New York: Teachers College Press.

Balfanz, R., \& Letgers, N. (2004). Locating the dropout crisis (Report 70). Baltimore: Center for the Social Organization of Schools. Johns Hopkins University.

Bijl, R. V., Zorlu, A., van Rijn, A. S., Jennissen, R. P. W., Blom, M. (2005). Integratiekaart 2005: De maatschappelijke integratie van migranten in de tijd gevolgd: trend-en cohortanalyses. The Hague, Netherlands: WODC/CBS.

Boog, I., Donselaar, J., Houtzager, D., Rodrigues, P., \& Schriemer, R. (2006). Monitor Rassendiscriminatie 2005 [Monitor race discrimination 2005]. Leiden, Netherlands: Universiteit van Leiden.

Cookson, P. W., Jr., \& Lucks, C. S. (1995). School choice in New York City: Preliminary 
observations, In M. T. Hallinan (Ed.), Restructuring schools: Promising practices and policies (pp 99-109). New York: Plenum Press.

Crul, M. (1994). Springen over je eigen schaduw. De onderwijsprestaties van Marokkanen en Turken van de tweede generatie [Jumping over your own shadow: The educational performance of second-generation Moroccans and Turks]. Migrantenstudies, 10(3), 168-186.

Crul, M. (2000). De sleutel tot succes. Over hulp, keuzes en kansen in de schoolloopbanen van Turkse en Marokkaanse jongeren van de tweede generatie [The key to success: On support, choices, and chances in the school careers of Turkish and Moroccan youth of the second generation]. Amsterdam: Het Spinhuis.

Crul, M., \& Doomernik, J. (2003). The Turkish and the Moroccan second generation in the Netherlands: Divergent trends between and Polarization within the two groups. International Migration Review, 37, 1039-1065.

Crul, M., \& Wolff, R. (2002). Talent gewonnen. Talent verspild? [Talent won. Talent wasted?] Utrecht, Netherlands: Echo.

Crok, S., Slot, J., Fedorova, T., Janssen, M., \& ten Broeke, L. (2004). Naar Burgerschap in Amsterdam [Toward citizenship in Amsterdam]. Amsterdam: Bestuursdienst Amsterdam.

Distelbrink, M., \& Hooghiemstra, E. (2006). Demografie [Demography]. In S. Kreuzenkamp \& A. Merens (Eds.), Sociale atlas van de vrouw uit etnische minderheden (pp. 18-38). Rijswijk, Netherlands: Social and Cultural Planning Office.

Gijsberts, M., \& Hartgers, M. (2005). Minderheden in het Onderwijs [Minorities in education]. In Jaarrapport Integratie 2005. Rijswijk, Netherlands: Social and Cultural Planning Office.

Grasmuck, S., \& Pessar, P. R. (1991). Between two islands: Dominican international migration. Berkeley: University of California Press.

Groeneveld, S., \& Weijers-Martens, Y. (2003). Minderheden in beeld, SPVA-2002 [Minorities in the picture, SPVA-2002]. Rotterdam, Netherlands: ISEO.

Guarnizo, L. E. (1994). Los Dominicanyorks: The making of a binational society (Trends in U. S.Caribbean Relations). Annals of the American Academy of Political and Social Science, 533(1), 7086.

Hernandez, R. (2002). The mobility of workers under advanced capitalism: Dominican migration to the United States. New York: Columbia University Press.

Herwijer, L. (2003). Voortgezet Onderwijs, beroepsonderwijs en hoger onderwijs [Secondary education, vocational training and tertiary education]. In J. Dagevos, M. Gijsberts, \& C. van Praag (Eds.), Rapportage Minderheden 2003 (pp. 111-142). Rijswijk, Netherlands: Social and Cultural Planning Office.

Itzigsohn, J., \& Dore-Cabral, C. (2000). Competing identities? Race, ethnicity and panethnicity among Dominicans in the United States. Sociological Forum, 15(2) 50-78..

Jennissen, R., \& Hartgens, M. (2007). Allochtonen in het onderwijs [Migrants in education]. In Integratie kaart 2006. De maatschappelijke integratie van migranten bepaald en gevolgd (pp. 1124). The Hague, Netherlands: WODC.

de Jong, M. (1997). De taak van het onderwijs en de volwasseneneducatie binnen een actief 
inburgeringsbeleid [The tasks of education and adult education in an active participation policy]. In M. Foblets \& B. Hubeau (Eds.), Nieuwe burgers in de samenleving? (pp. 155-171). Leuven, Netherlands: Acco.

de Jong, W. (1986). de Interetnische verhoudingen in een oude stadswijk [Interethnic relations in an old city district]. Delft, Netherlands: Eburon.

Junger-Tas, J., Cruyff, M., van de Looij-Jansen, P., \& Reelick, F. (2003). Etnische Minderheden en het belang van binding [Ethnic minorities and the importance of belonging]. The Hague, Netherlands: Sdu.

Kasinitz, P., Mollenkopf, J., Waters, M., \& Holdaway, J. (2008). Inheriting the city: The second generation comes of age. Cambridge, MA: Harvard University Press/Russell Sage Foundation.

Kerckhoff, A. C. (1995). Reforming education: A critical overlooked component. In M. T. Hallinan (Ed.), Restructuring schools: Promising practices and policies (pp. 199-231). New York: Plenum Press, 1995.

Kozol, J. (1991). Savage inequalities: Children in America's schools. New York: Harper Collins

Levitt, P. (1991). The transnational villagers. Berkeley: University of California Press.

Lipsit, M. (2003). Newcomers left behind: Immigrant parents lack equal access to New York City's schools. New York: Center for New York City Affairs, Milano Graduate School of Management and Urban Policy, New School University.

Logan, J. R. (2001). The new Latinos: Who they are, where they are. Research report, Lewis Mumford Center for Comparative Urban and Regional Research, State University of New York, Albany.

Logan, J. R. (2002). Hispanic populations and their residential patterns in the metropolis. Research report, Lewis Mumford Center for Comparative Urban and Regional Research, State University of New York, Albany.

Lopez, N. (2004). Hopeful girls, troubled boys: Race and gender disparity in urban education. New York: Routledge, 2004.

Louie, V., \& Holdaway, J. (2009). Catholic schools and immigrant students: A new generation. Teachers College Record, 111(3).

Massey, D. S., \& Denton, N. A. (1993). American apartheid. Cambridge, MA: Harvard University Press.

Mei, L., Bell-Ellwanger, J., \& Miller, R. (2002, April). An examination of four year cohort graduation and dropout rates for the New York City schools' class of 2001 and final school completion outcomes for the class of 1990. Paper presented at the annual meeting of the American Education Research Association, New Orleans, LA.

Musterd, S., \& Deurloo, M. C. (2002). Unstable immigrant concentrations in Amsterdam: Spatial segregation and integration of newcomers. Housing Studies, 17, 487-503.

New York City Board of Education. (2001). Chancellor's report. New York: Author.

Oakes, J. (1985). Keeping track: How schools structure equality. New Haven, CT: Yale University Press. 
Orfield, G., \& Yun, J. T. (1999). Resegregation in American schools. Cambridge, MA: Civil Rights Project, Harvard University.

Pessar, P. R. (1995). Visa for a dream: Dominicans in the United States. Boston: Allyn and Bacon.

Rosenbaum, J. E. (2001). Beyond college for all: Career paths for the forgotten half. New York: Russell Sage Foundation.

Teske, P., Schneider, M., Roch, C., \& Marschall, M. (2000). Public school choice: A status report. In D. Ravitch \& J. Viteritti (Eds.), City schools: Lessons from New York (pp. 313-338). Baltimore: Johns Hopkins University Press.

Tesser, P., Merens, J., \& van Praag, C. (1999). Rapportage minderheden 1999 [Report on minorities 1999]. Rijswijk: Social and Cultural Planning Office.

Turkenburg, M., \& Gijberts, M. (2006). Onderwijs en inburgering [Education and becoming naturalized]. In S. Kreuzenkamp \& A. Merens (Eds.), Sociale atlas van de vrouw uit etnische minderheden (pp. 39-67). Rijswijk, Netherlands: Social and Cultural Planning Office, 2006.

Cite This Article as: Teachers College Record Volume 111 Number 6, 2009, p. 4-5

http://www.tcrecord.org/Home.asp ID Number: 15332, Date Accessed: 9/12/2008 8:46:41 AM

Purchase Reprint Rights for this article or review 